\title{
Persepsi Masyarakat Terhadap Pengelolaan Hutan Kota di Kota Serang
}

\author{
Anis Masyruroh \\ Universitas Serang Raya \\ Surel: anismasyrurh@gmail.com
}

\begin{abstract}
ABSTRAK
Hutan kota selain memiliki fungsi lingkungan dan ekonomi, akan tetapi memiliki fungsisosial yang tidak kalah penting. Fungsi sosial dari hutan keberadaan hutan kota salah satu contohnya adalahbanyaknya masyarakat yang memilih berkunjung ke hutan kota hanya untuk sekedar mencari udara segar dan melihat penghijauan yang ada disekitarnya. Penelitian ini difokuskan pada persepsi masyarakat terhadap pengetahuan masyarakat, persepsi rasa nyaman dan persepsi tentang sarana pendidikan yang dihasilkan dari pembangunan hutan kota di Kota Serang dengan menggunakan uji kuesioner. hasil dari penelitian ini adalah, menunjukan bahwa mayoritas masyarakat memiliki pengetahuan tentang hutan kota, sehingga dari pengetahuan tersebut mayoritas masyarakat memiliki persepsi rasa nyaman apabila hutan kota dihadirkan di Kota Serang. Demikian juga persepsi masyarakat terhadap hutan kota dapat menjadi sarana pendidikan, mayoritas masyarakat menyetujui bahwa hutan kota dapat dijadikan sebagai sarana pendidikan.
\end{abstract}

\section{Kata kunci}

Hutan kota, Masyarakat, Lingkungan

\section{PENDAHULUAN}

Kota adalah suatu permukaan wilayah administrasi pemerintahan dengan berbagai jenis aktifitas manusia berupa ekonomi, sosial budaya yang pada akhirnya membentuk sentralisasi penduduk ${ }^{[1]}$. Dampak langsung dari pembangunan fasilitas dan utilitas kota terlihat dari adanya konversi ruang terbuka hijau yang terjadi terus menerus, akibat dari semakin sempitnya ruang terbuka hijau. Data Badan Statistik Kota Serang menunjukkan titik ruang terbuka hijau sebanyak 39\% dari luasan wilayah Kota Serang pada tahun 2010, saat ini berkurang menjadi $35 \%$ di tahun $2016^{[2]}$. Peristiwa penurunan ini jika dibiarkan seiring dengan pertumbuhan penduduk yang berkisar $2 \%$ per tahun akan mengakibatkan semakin meningkatnya persoalan lingkungan di Kota Serang.
Berdasarkan pengamatan di lapangan, keberadaan hutan kota di Kota Serang masih belum memenuhi standar, seperti hutan kota Kota Serang memiliki luas 1,4 hektar ${ }^{[3]}$ luas ini belum memenuhi persyaratan Peraturan Perundangan.No.63 Tahun 2002 yaitu luas hutan kota $10 \%$ dari luas wilayah kota, kemudian juga distribusi hutan kota yang belum merata dan kualitas hutan kota yang masih rendah serta pengelolaan hutan kota yang belum serius. Sehingga perlu ditingkatkan pengelolaannya agar fungsinya dalam memberikan pelayanan lingkungan yang dihasilkan oleh hutan kota dapat dirasakan secara langsung seperti hutan kota dapat dijadikan sebagai tempat resapan air yang dapat digunakan sebagai sumber kehidupan masyarakat, hutan kota dapat digunakan sebagai tempat rekreasi masyarakat 
di sekitar Kota Serang, hutan kota dapat difungsikan sebagai investasi ekonomi, hutan kota dapat diandalkan sebagai kawasan penyerapan $\mathrm{CO}^{2}$, hutan kota dapat difungsikan sebagai peredam kebisingan kota dan lain-lain, sehingga perlu adanya penambahan luasan terhadap hutan kota dengan penambahan vegetasi di dalam areanya dan dengan sebaran yang merata di Wilayah Kota.

Hutan kota selain memiliki fungsi lingkungan dan ekonomi, akan tetapi memiliki fungsisosial yang tidak kalah penting. Fungsi sosial dari hutan keberadaan hutan kota salah satu contohnya adalahbanyaknya masyarakat yang memilih berkunjung ke hutan kota hanya untuk sekedar mencari udara segar dan melihat penghijauan yang ada di sekitarnya.

\section{METODE PENELITIAN}

Penelitian ini difokuskan pada persepsi masyarakat terhadap pengetahuan masyarakat, persepsi rasa nyaman dan persepsi tentang sarana pendidikan yang dihasilkan dari pembangunan hutan kota di Kota Serang. Metode penelitian ini dengan survei dengan teknik pertanyaan dengan dibantu lewat menyebarkan kuesioner kepada responden. Responden dari penelitian ini adalah masyarakay yang berkunjung terhadapa taman kota yang ada di Kota Serang. Pengambilan responden untuk penentuan sampel kuesioner dilakukan dengan menggunakan purposive sampling yaitu teknik penentuan sampel dengan pertimbangan tertentu. Penentuan jumlah responden menggunakan rumus Slovin $^{[5]}$.

$$
n=\frac{N}{1+N e^{2}}
$$

$$
\begin{aligned}
& \text { Dimana } \mathrm{n}=\text { Jumlah Sampel } \\
& \mathrm{N}=\text { Jumlah Populasi } \\
& \text { e = Batas Toleransi Kesalahan }
\end{aligned}
$$

Dari hasil perhitungan tersebut, maka responden yang dijadikan sampling kuesioner adalah 100 responden.

\section{HASIL DAN PEMBAHASAN}

Berdasarkan hasil wawancara yang dilakukan terhadap pengunjung hutan kota, tingkat pengetahuan responden terhadap hutan kota menunjukan responden yang menjawab tahu berada pada hasil yang tertinggi. Adapun diagram yang menunjukkan pengetahuan tentang hutan kota ditunjukkan oleh Gambar 1.

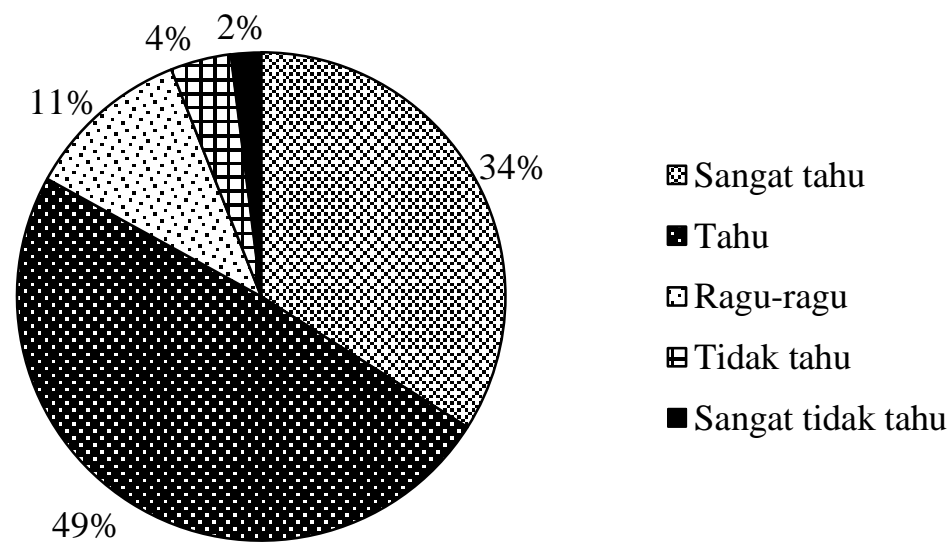

Gambar 1. Pengetahuan tentang hutan kota

Berdasarkan Gambar 1 di atas diketahui bahwa responden sebanyak $49 \%$ mengetahui tentang hutan kota, sementara itu yang memiliki pengetahuan sangat tahu tentang hutan kota sebanyak 34\%, responden yang ragu ragu sebesar $11 \%$, pengetahuan tidak tahu $4 \%$ dan pengetahuan sangat tidak tahu sebesar $2 \%$. 
Gambar menunjukkan bahwa masyarakat Kota Serang pada umumnya mengetahui yang dimaksud dengan hutan kota, hal ini tergambar sebanyak $49 \%$ menyatakan bahwa mereka mengetahui apa yang dimaksudkan dengan hutan kota, hal ini membuktikan bahwa sebagain besar masyarakat/ responden sudah mengerti dan memahami apa yang dimaksudkan dengan hutan kota dimana informasi yang mereka dapatkan berasal dari berbagai sumber, ada yang mendapatkan informasi dari majalah, media elektronik maupun dari teman atau saudara. Masyarakat/responden juga setuju dengan adanya hutan kota, $100 \%$, karena masyarakat/responden berpendapat bahwa dengan adanya hutan kota akan memberikan kesejukan, keindahan dan kenyamanan serta akan mengurangi polusi udara. Masyarakat/responden mengatakan bahwa kondisi hutan kota Kota Serang dalam kondisi rusak dan tidak terawat dengan baik, masyarakat mengharapkan adanya peran aktif dari pemerintah Kota Serang untuk memperhatikan keberadaan hutan kota yang ada di Kota Serang sehingga kondisi hutan kota yang rusak akan terawat dengan baik. Masyarakat/responden berpendapat bahwa hutan kota yang di butuhkan di Kota Serang adalah taman kota berupa pohon-pohon yang rindang dan hijau sehingga dapat memberikan kesejukan dan kenyamanan bagi masyarakat kota. Hal ini terkait dengan keindahan Kota
Serang yang kurang baik akibat banyaknya pencemaran yang terjadi seperti pencemaran debu dan tingkat kebisingan yang tinggi. Tingkat pemahaman masyarakat Kota Serang dapat dipengaruhi oleh pengetahuan yang didapatkan dari berita dan informasi yang berhubungan dengan hal-hal mengenai hutan kota. Selain itu, faktor pendidikan juga dapat mempengaruhi tingkat persepsi seseorang. Tingkat persepsi tersebut menggambarkan bahwa masyarakat sudah memahami tentang aspek pengenalan hutan kota yang dipengaruhi oleh banyaknya informasi mengenai hal-hal terkait dengan hutan kota. Hal ini sesuai dengan pernyataan Pamungkas (2006) yang menyatakan bahwa persepsi adalah suatu gambaran pengertian serta interpretasi seseorang mengenai suatu obyek, terutama bagaimana orang tersebut menghubungkan informasi itu dengan dirinya dan lingkungan ia berada.

\section{Persepsi Tingkat Kenyamanan Masyarakat Terhadap Keberadaan Hutan Kota \\ Persepsi kenyamanan masyarakat} terhadap keberadaan hutan kota untuk mengetahui tingkat kenyamanan yang dirasakan masyarakat terhadap keberadaan hutan kota. Lebih jelasnya penilaian persepsi kenyamanan masyarakat terhadap keberadaan hutan kota dapat dijelaskan pada Gambar 2 berikut ini.

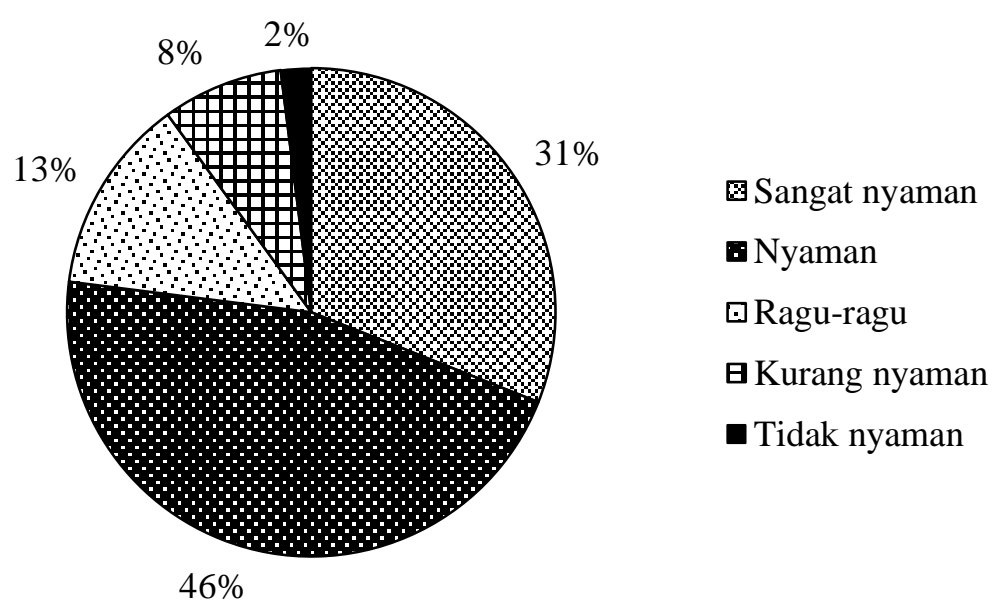

Gambar 2. Persepsi kenyamanan masyarakat terhadap keberadaan hutan kota 
Berdasarkan gambar 2 tingkat persepsi kenyamanan masyarakat terhadap keberadaan hutan kota, pada umumnya masyarakat memiliki persepsi akan merasa nyaman dengan adanya hutan kota, dapat dilihat dari hasil responden yang merasa nyaman sebesar 46\% menyatakan bahwa keberadaan hutan kota akan berdampak pada rasa nyaman terhadap kota. responden yang merasa sangat nyaman sebesar $31 \%$, responden yang merasa ragu-ragu sebesar 13\%, kurang nyaman $8 \%$ dan $2 \%$ responden merasa tidak nyaman.

Persepsi tentang kenyamanan masyarakat terhadap keberadaan hutan kota disebabkan karena hutan kota memberikan kesejukan dengan banyak mengeluarkan oksigen dan dapat menahan sinar matahari, sehingga masyarakat yang berkunjung ke hutan kota pada umumnya mencari kesejukan dan mengharapkan mendapatkan suplai oksigen yang lebih segar.

\section{Persepsi Tingkat Sarana Pendidikan Masyarakat Terhadap Hutan Kota}

Berdasarkan hasil kuesioner, dalam persepsi masyarakat akan sarana pendidikan terhadap hutan kota menunjukan bahwa keberadaan Hutan Kota dapat digunakan untuk kepentingan pendidikan, penelitian dan pengembangan ilmu pengetahuan terdapat pada Gambar 3 berikut.

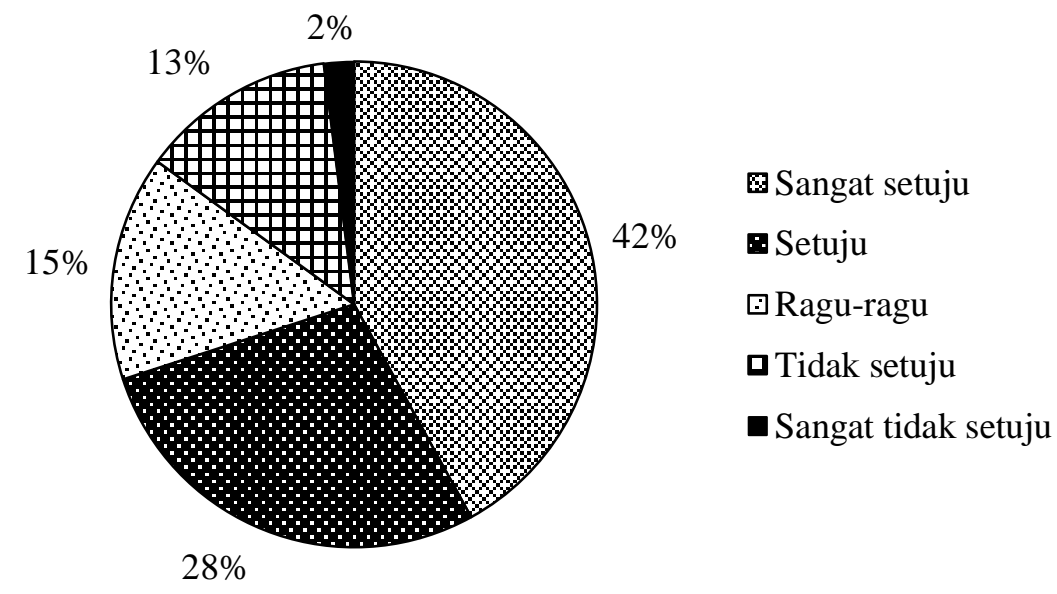

Gambar 3. Persepsi masyarakat akan sarana pendidikan terhadap hutan kota

Gambar 3 di atas memperlihatkan bahwa $42 \%$ dari responden mengatakan sangat setuju bahwa hutan kota sebagai tempat atau sarana pendidikan, $28 \%$ mengatakan setuju, $15 \%$ ragu-ragu, $13 \%$ mengatakan tidak setuju dan $2 \%$ responden mengatakan sangat tidak setuju.

Dari hasil gambar di atas menunjukan bahwa sebanyak $42 \%$ masyarakat menyetujui bahwa hutan kota dapat dijadikan sebagai sarana pendidikan, hal ini dipengaruhi oleh pengetahuan masyarakat tentang hutan kota di Kota Serang sebagaimana telah disampaikan di atas bahwa tingkat pengetahuan sebagian masyarakat terhadap hutan kota cukup tinggi, sehingga memungkinkan masyarakat untuk mengetahui bahwa salah satu fungsi dari hutan kota adalah dapat dijadikan sebagai sarana pendidikan.

\section{KESIMPULAN}

Untuk hasil analisis hubungan hutan kota terhadap sosial, menunjukan bahwa mayoritas masyarakat memiliki pengetahuan tentang hutan kota, sehingga dari pengetahuan tersebut mayoritas masyarakat memiliki persepsi rasa nyaman apabila hutan kota dihadirkan di Kota Serang. Demikian juga persepsi masyarakat terhadap hutan kota dapat menjadi sarana pendidikan, mayoritas masyarakat menyetujui bahwa hutan kota dapat dijadikan sebagai sarana pendidikan. 


\section{REFERENSI}

[1] Adisasmita, R., 2015, Pembangunan Wilayah, Yogyakarta, Graha Ilmu.

[2] Badan Perencanaan Pembangunan Daerah Kota Serang, 2016), RTRW Kota Serang 2010-2030, Kota Serang, Badan Perencanaan Pembangunan.

[3] Badan Perencanaan Pembangunan Daerah Kota Serang. (2015). Pendataan
Pembangunan Industri 2013 dan 2014. Pembangunan Perumahan 2015. Kota Serang: Badan Perencanaan Pembangunan Daerah.

[4] Peraturan Pemerintah RI No. 63 Tahun 2002 tentang Hutan Kota.

[5] Amirin, T., 2011, Populasi Dan Sampel Penelitian 4: Ukuran Sampel Rumus Slovin, Jakarta, Erlangga. 